\title{
MODA E CONSUMO SUSTENTÁVEL: UM EXEMPLO DE FLORIANÓPOLIS (SC)
}

\section{FASHION AND SUSTAINABLE CONSUMPTION: AN EXAMPLE FROM FLORIANÓPOLIS (SC)}

\author{
VALDECIR BABINSKI JÚNIOR | UDESC \\ PAULA MARTIN | UNISUL \\ MARIANA LUÍSA SCHAEFFER BRILHANTE |UDESC \\ LUCAS DA ROSA, Dr. | UDESC \\ DULCE MARIA HOLANDA MACIEL, Dra. | UDESC
}

\begin{abstract}
RESUMO
Com o objetivo de verificar por meio de um negócio de Moda, de Florianópolis (SC), como se configura o consumo sustentável localmente, o presente artigo explora o exemplo da marca de bolsas e de acessórios Black Purpurin. Como hipótese, estima-se que consumidores locais procuram pela empresa por sua ênfase na sustentabilidade e, de modo recíproco, ela Ihes legitima o comportamento pró-sustentabilidade. Metodologicamente, este artigo enquadra-se como pesquisa aplicada, qualitativa, descritiva, bibliográfica e de campo. Utilizou-se como instrumento de coleta de dados uma entrevista roteirizada com vinte perguntas abertas destinadas à coproprietária da marca. A literatura foi investigada à luz do Objetivo de Desenvolvimento Sustentável (ODS) 12 - Consumo e Produção Sustentáveis — da Organização das Nações Unidas (ONU). Por fim, a hipótese traçada pelos autores foi refutada no exemplo verificado e se evidenciou que os consumidores locais buscam exercer o poder de consumo por intermédio de aspectos estéticos-formais e valores imateriais. Ou seja, antes de critérios sustentáveis, estes valorizam o design, a exclusividade, a possibilidade de customização e o processo de impressão em 3D das peças comercializadas pela marca supracitada.
\end{abstract}

PALAVRAS-CHAVE: Moda; Ecomoda; Consumo sustentável; Consumo ético; Objetivos de Desenvolvimento Sustentável.

\begin{abstract}
In order to verify through a Fashion business in Florianópolis (SC), how sustainable consumption is configured locally, this article explores the example of the Black Purpurin handbag and accessory brand. As a hypothesis, it is estimated that local consumers look for the company for its emphasis on sustainability and, in a reciprocal way, it legitimizes their pro-sustainability behavior. Methodologically, this article fits as applied, qualitative, descriptive, bibliographic and field re-search. As a data collection instrument, a scripted interview with twenty open questions for the co-owner of the brand was used. The literature was investigated in the light of Sustainable Development Objective (SDG) 12 - Sustainable Consump-tion and Production - of the United Nations (UN). Finally, the hypothesis outlined by the authors was refuted in the verified example and it was evidenced that local consumers seek to exercise the power of consumption through aesthetic-formal aspects and immaterial values. That is, before sustainable criteria, they value the design, exclusivity, the possibility of cus-tomization and the 3D printing process of the pieces sold by the aforementioned brand.
\end{abstract}

KEY WORDS: Fashion; Ecofashion; Sustainable consumption; Ethical consumption; Sustainable Development Goals. 


\section{INTRODUÇÃO}

Há muito Moda e consumo dialogam. Surgida entre os Séculos XVIII e XIX, durante a Revolução Industrial, a articulação entre o consumidor e os negócios de Moda implicou e continua a implicar no conhecimento das diferentes motivações embutidas na relação pessoa-objeto. Enquanto manifestação social do indivíduo, a Moda cumpre dois papéis na relação supracitada: por um lado, ela instrumentaliza os indivíduos ao permitir a exteriorização de suas personalidades; por outro lado, associada ao consumo, ela cria desejo sobre os bens materiais que, por meio de uma comunicação eficiente, adquirem qualidades intangíveis e permutáveis aos indivíduos (LIPOVETSKY, 2009).

Isto implica dizer que ao adicionar um bem material aos seus pertencimentos, os indivíduos podem projetar a aquisição, também, de suas qualidades de ordem imaterial. Nesse sentido, se o objeto se apresentar belo, logo, também seu usuário e proprietário será belo. À Moda cabe acentuar tais qualidades e seduzir os indivíduos por meio do apelo aos desejos de consumo. Para tanto, a Moda apoia-se na estetização do capital e no jogo das aparências. Não raro, em meio ao anseio por se tornar aquilo que compram, os indivíduos acabam por negligenciar as questões pró-sustentabilidade relacionadas ao consumo e à produção de bens materiais (SCHULTE, 2015).

Nessa perspectiva, destaca-se a criação da Agenda 30 para o Desenvolvimento Sustentável, um plano de ação com foco em erradicar a pobreza e assegurar a proteção ao planeta e às pessoas por meio da paz e da prosperidade. $\mathrm{O}$ documento foi publicado em setembro de 2015, após reuniões de cúpula da Organização das Nações Unidas (ONU), que ocorreram em sua sede em Nova York (EUA) e integraram líderes mundiais e especialistas em sustentabilidade. $\mathrm{A}$ Agenda 30, estipulou os 17 Objetivos de Desenvolvimento Sustentável (ODS), entre eles, importa ressaltar o ODS 12 Consumo e Produção Sustentáveis (UN, 2019).

Conforme consulta ao endereço eletrônico e institucional da ONU (2015), compreende-se que, tal qual os outros 16 ODS, o ODS 12 tem como pilares: (I) pessoas; (II) planeta; (III) prosperidade; (IV) paz universal; e (V) parceria. Segundo documento do Ministério das Relações Exteriores do Brasil (2016), o objetivo do ODS 12 está em assegurar padrões de produção e de consumo sustentáveis e implementar programas relacionados ao tema em todos os países signatários. $\mathrm{O}$ documento orienta que os países do primeiro mundo devem assumir o papel de liderança, sem desconsiderar, no entanto, o desenvolvimento e a capacidade dos países do terceiro mundo. Para tanto, metas são apresentadas até o ano de 2020: (I) alcançar o uso ambientalmente apropriado para produtos químicos e resíduos, segundo os marcos internacionais; (II) reduzir expressivamente a contaminação do ar, da água e do solo; e (III) mitigar os prejuízos à vida humana e ao meio ambiente.

Para o ano de 2030, as metas estipuladas são: (I) minimizar a geração de resíduos por intermédio de estratégias de prevenção, de redução, de reciclagem e de reúso; (II) promover o alcance de informações relevantes voltadas para a conscientização sobre o desenvolvimento sustentável para o maior número de pessoas possível, assim como fomentar estilos de vida em equilíbrio com a natureza; (III) atingir um patamar avançado na gestão sustentável e no uso eficiente dos recursos do planeta; e (IV) cortar pela metade o desperdício mundial de alimentos per capita ao longo de toda a cadeia de produção e de abastecimento, desde a pós-coIheita até o varejo e o consumidor (UN, 2019).

Traduzido pelo Centro de Informação das Nações Unidas para o Brasil (UNIC Rio) e revisado pela Coordenadoria Geral de Desenvolvimento Sustentável (CGDES), o documento ainda sinaliza que o ODS 12 tem outros objetivos, além dos supramencionados, a saber: (I) incentivar empresas no sentido da adoção de práticas sustentáveis e da integração da sustentabilidade como parte do ciclo de seus respectivos relatórios; (II) fomentar a ênfase na sustentabilidade mediante políticas e prioridades nacionais, em especial, no tangente às compras públicas; (III) apoiar o desenvolvimento científico e tecnológico de países de terceiro mundo com foco em padrões de produção e de consumo pró-sustentabilidade; (IV) construir e implementar formas de monitoramento do turismo sustentável, de modo a incentivar a geração de empregos e a promoção da cultura local; e (V) racionar, inteligentemente, subsídios ineficientes aos combustíveis fósseis, de maneira tal que sejam eliminadas distorções de mercado e impactos adversos quanto ao consumo exagerado que, por sua vez, deve ser desencorajado (MINISTÉRIO DAS RELAÇÕES EXTERIORES DO BRASIL, 2016).

Nesse sentido, à sombra da ODS 12, o presente artigo tem como objetivo verificar por meio de um negócio de Moda, de Florianópolis (SC), como se configura o consumo sustentável localmente. A hipótese dos autores deste estudo consiste em: os consumidores locais procuram pelo negócio de Moda por sua ênfase declarada na sustentabilidade e, de modo recíproco, a empresa legitima o comportamento pró-sustentabilidade por meio de ações que ultrapassam o ato de compra.

A importância da realização desta pesquisa dá-se mediante a compreensão do consumo simbólico na contemporaneidade, elucidada por intermédio do 
comportamento pró-sustentabilidade - que, conforme observam Lima et al. (2018) e Morelli (2018), ainda se encontra em formação no horizonte da Moda. Para as autoras, à medida que a sociedade de consumo passa a integrar requisitos de sustentabilidade no ato de compra, também às Indústrias Têxteis e de Confecção, tais quais outros tantos negócios de Moda, devem responder inteligentemente ao novo status do consumo.

Sob tal perspectiva, acredita-se que o artigo pode ser relevante para o mercado pois torna-se possível estabelecer novas discussões para equacionar o comportamento pró-sustentabilidade mediante os consumidores locais. Na visão de Fajardo (2010), de modo geral, o público-alvo dos mercados contemporâneos pode ser compreendido como ávido por opções de compra sustentáveis, inovadoras e voltadas para o bem comum. A sustentabilidade, tal qual se busca investigar neste artigo, não afeta apenas estratégias de fomento ao consumo ou o marketing de empresas: ela também influencia decisões de nível tático e operacionais, o modo como emprega-se a força de trabalho, a conexão entre consumidores e comunidades, entre outros vários quesitos.

Quanto à contribuição deste artigo ao meio acadêmico, destaca-se o ensejo e a oportunidade de aplicar os conhecimentos teóricos acerca dos ODS em uma prática empresarial. O registro da transferência do conhecimento e da confrontação entre teoria e prática pode vir a ser utilizado, futuramente, para a construção de outros estudos que visem articular Moda, consumo e produção sustentáveis. Ademais, assim como sublinha Schulte (2015), toda e qualquer contribuição à discussão sobre Moda e sustentabilidade dever ser bem-vinda ao contexto acadêmico pois ainda são parcas as publicações de cunho científico na área.

Assim, a seguir, apresenta-se o referencial teórico do corpo de conhecimento deste artigo, os procedimentos metodológicos nele empregados, o exemplo da empresa florianopolitana, a discussão objetivada e as considerações finais que encerram o estudo.

\section{DESENVOLVIMENTO SUSTENTÁVEL}

A necessidade ecológica de conservação das riquezas naturais e sua harmonia com o crescimento econômico das sociedades foi tema de inúmeras discussões na ONU ao longo das últimas décadas. Segundo Figueiró (2001), desde a criação da Agenda 21 pelos países participantes da II Conferência das Nações Unidas para o Meio Ambiente e Desenvolvimento Humano, ocorrida entre 3 e 14 de junho de 1992, e também conhecida como Rio 92 ou Eco 92, a Cúpula da Terra discute o crescimento humano versus a capacidade de renovação e os limites dos recursos planetários.
As discussões que se seguiram durante a Eco 92 apoiaram-se nos preceitos de John Elkington que, em 1990, havia criado o conceito de triple bottom line - chamado, atualmente, de tripé da sustentabilidade. À época, como coordenador da Organização não Governamental (ONG) internacional Sustainability, Elkington definiu três pilares fundamentais para a compreensão da sustentabilidade: (I) o pilar social, relativo ao capital humano; (II) o pilar ambiental, relacionado com o capital natural; e (III) o pilar econômico, articulado ao capital financeiro. Os pilares de Elkington aplicavam-se tanto para nações, como para empresas, grupos sociais e/ou indivíduos (SCHULTE, 2015).

Schulte (2015) assevera que, a partir de Elkington, passou-se a considerar o tripé da sustentabilidade como indispensável para garantir às gerações futuras o acesso a um meio ambiente saudável. Ainda durante a Eco 92, surgiu a compreensão de que o consumo não se encontrava como um processo isolado e hermético, que começava ou acabava no momento da compra, mas poderia ser visto como um processo fluído, multidimensional e flexível, pois se moldava, individualmente, aos sujeitos da contemporaneidade. Realizadas as discussões pertinentes, o documento gerado na conferência foi fixado e assinado por 176 países, entre eles, o Brasil. Para Barbieri (2011, p. 83),

Apesar de todos os problemas que envolvem sua implementação, [...] a Agenda/Programa 21 , constitui um grande guia para se alcançar o desenvolvimento sustentável. Ela é um grande inventário dos problemas que a humanidade enfrenta e das providências necessárias para enfrentá-los, dentro de uma perspectiva global [...].

Barbieri (2011) assinala que a Agenda 21 serviu de receituário para guiar a humanidade rumo a um desenvolvimento que seja, ao mesmo tempo, socialmente justo e ambientalmente correto. Figueiró (2001) cita que a Agenda 21 Brasileira só foi criada, efetivamente, 5 anos após a conferência, em fevereiro de 1997 pela Comissão de Políticas de Desenvolvimento Sustentável. Tal comissão possibilitava aporte financeiro para projetos de formulação e de implementação de políticas públicas compatíveis com os princípios da Agenda 21 da ONU. O subsídio viria de um convênio firmado entre o Programa das Nações Unidas para o Desenvolvimento (PNUD) e o Ministério do Meio Ambiente do então governo Fernando Henrique Cardoso.

Segundo Figueiró (2001), a Agenda 21 Brasileira tinha como pilares: (I) cidade; (II) turismo; (III) saúde; (IV) educação; (V) meio ambiente; (VI) política; e (VII) sociedade. $A$ agenda recomendava que, por meio de fóruns municipais constituídos por representantes da sociedade e 
do governo, cada cidade e cada estado estabelecesse sua própria agenda. Nessa perspectiva, surgiu a Agenda 21 Catarinense e a Agenda 21 Florianópolis. A primeira abordava seis grandes áreas: (I) agricultura sustentável; (II) cidades sustentáveis; (III) infraestrutura e integração regional; (IV) gestão de recursos hídricos; (V) redução das desigualdades; e (VI) ciência e tecnologia para o desenvolvimento sustentável. A segunda, voltada para a cidade de Florianópolis (SC), estipulava a criação e as atribuições do Fórum 21 Local, a saber: (I) representar os interesses da comunidade; (II) propor grupos de trabalhos temáticos; (III) fornecer subsídios à Câmara Municipal e ao prefeito sobre a constituição de políticas públicas favoráveis ao desenvolvimento sustentável; (IV) sugerir a alocação de recursos em projetos pró-sustentabilidade; (V) tornar públicos relatórios de suas atividades e de seus encontros; e (VI) acompanhar auditorias sempre que necessário.

A Agenda 21 Florianópolis ainda estipulava como indicadores locais: (I) a redução do desperdício de riquezas de ordem natural, financeira e humana; (II) o controle da degradação ambiental à nível de município; (III) a minimização do volume de lixo comum gerado na cidade e o provimento de melhor tratamento para os resíduos industriais e hospitalares; (IV) a melhoria nas condições de moradia e de habitação, bem como, o acesso ao saneamento básico e à provisão de água; $(V)$ o incremento estratégico para o progresso da educação básica, da saúde e da higiene dos sujeitos citadinos; (VI) a ascensão às oportunidades de cultura, lazer e recreação; (VII) o fomento de novas possibilidades de trabalho regular; e (VIII) o alcance direto e transparente às informações e aos processos de tomada de decisão dos líderes do governo municipal (FIGUEIRÓ, 2001).

Passadas duas décadas da proposição da Agenda 21, os representantes de diversas nações do mundo se reencontraram para discutir o desenvolvimento econômico em alinhamento aos recursos naturais. A Rio+20, Conferência das Nações Unidas Sobre O Desenvolvimento Sustentável, foi realizada entre 13 e 22 de junho de 2012, na cidade do Rio de Janeiro (RJ). A conferência ficou assim conhecida por, a partir dos acordos firmados na Rio 92, propor a renovação do compromisso político com o desenvolvimento sustentável por intermédio da economia verde. A avaliação do progresso e das lacunas acerca das estratégias que deveriam ter sido implementadas no decorrer das duas últimas décadas foi pauta das principais reuniões de cúpula no evento (UN, 2020).

A partir da declaração final da conferência Rio+20 documento intitulado $O$ futuro que queremos - foi realizado um processo intergovernamental de consulta global sobre o desenvolvimento sustentável durante o período de três anos. Assim, em setembro de 2015, líderes mundiais reunidos na sede de Nova York (EUA) da ONU, criaram um plano de ação que recebeu o nome de Agenda 2030 para o Desenvolvimento Sustentável. Essa nova agenda tinha como intuito promover a erradicação da pobreza, proteger os recursos naturais e fomentar a paz e a prosperidade entre as nações do mundo. Ela continha 17 objetivos, chamados de Objetivos de Desenvolvimento Sustentável (ODS) (UN, 2020).

Para a construção dos ODS, o grupo de especialistas da ONU, em conjunto com líderes mundiais, tomou como base os Objetivos de Desenvolvimento do Milênio (ODM) que surgiram em cúpulas multilaterais realizadas desde a década de 1990 com foco na redução da miserabilidade extrema. Para Figueiró (2001), os ODM — também chamados de Metas do Milênio - eram descritos como: (I) erradicar a extrema pobreza e a fome; (II) atingir o ensino básico universal; (III) promover a igualdade de gênero e a autonomia das mulheres; (IV) reduzir a mortalidade infantil; (V) melhorar a saúde materna; (VI) combater o HIV/AIDS, a malária e outras doenças; (VII) garantir a sustentabilidade ambiental; e (VIII) estabelecer uma parceria mundial para o desenvolvimento sustentável. Diferentemente dos ODS, as Metas do Milênio incluem os países em desenvolvimento como principais agentes articuladores da economia verde.

Aceitos por todos os países e aplicável em todas as nações, os ODS apontam diretrizes que devem ser completadas ou implementadas até o ano de 2030. Entre os 17 objetivos, sublinham-se direcionamentos para políticas nacionais no sentido da cooperação mundial pelo desenvolvimento sustentável. Tais direcionamentos apontam que cada país, a partir de sua realidade, de sua capacidade financeira e de seu aprimoramento tecnológico, deve buscar equilibrar o tripé entre justiça social, preservação ambiental e crescimento econômico (MINISTÉRIO DAS RELAÇÕES EXTERIORES, 2016).

Em nível nacional, as empresas que colocam em prática um ou mais dos ODS podem ser reconhecidas por meio do Fórum Brasil ODS. Em 2019, nos dias 28 e 29 de junho, o fórum foi sediado pela cidade de Florianópolis (SC), sob coordenação do Movimento Nacional ODS Santa Catarina e da Editora Expressão. O evento reuniu um público de mais de 500 pessoas, entre eles microempresários, colaboradores de grandes empresas, líderes sociais, representantes de ONG, especialistas da área da sustentabilidade e acadêmicos. Durante o fórum, algumas empresas do estado receberam o Prêmio ODS Santa Catarina 2019 (BERGMANN, 2019). 
Na categoria Organização da Sociedade Civil, foi premiada a Associação Social Good Brasil, por seu projeto Laboratório SGB. Na categoria Pessoa Física, reconheceu-se o impacto de Carina Zagonel com a iniciativa Armário Coletivo, expoente e exemplo de mercado de redistribuição no estado. Na categoria Poder Público, a Prefeitura Municipal de Itajaí (SC) foi premiada pelo Planejamento Estratégico do Município de Itajaí (PEMI), que estipula metas a serem cumpridas até o ano de 2040. Na categoria Instituição de Ensino, o câmpus de Gaspar (SC) do Instituto Federal de Santa Catarina (IFSC) foi laureado pelo projeto Acolhimento e inclusão social a refugiados e imigrantes. Na categoria Organização de classe, foi premiado o projeto ReÓleo, da Associação Comercial e Industrial de Florianópolis (ACIF). Por fim, na categoria Empresas, recebeu reconhecimento do Movimento Nacional ODS Santa Catarina a empresa Campos Novos Energia S/A e seu projeto Enercan - Concurso Cultural "Sabe o lixo? Virou Arte!" (BERGMANN, 2019).

Em consulta sobre o ODS 12 ao endereço eletrônico do Movimento Nacional ODS Santa Catarina, fez-se possível visualizar uma listagem com caminhos recomendáveis para se atingir o consumo e a produção sustentáveis, a saber: (I) favorecer a aquisição de bens materiais duráveis mais do que a de bens descartáveis; (II) dar preferência ao uso da produção local e os produtos dela provenientes, acima da produção global e dos produtos estrangeiros; (III) compartilhar bens materiais e colocar de lado o consumo egoísta e individualista; (IV) buscar o aproveitamento integral dos insumos e dos produtos e evitar quaisquer desperdícios; (V) eleger produtos saudáveis e implementar estilos de vida salutares; (VI) estimular o acesso virtual aos produtos e às informações no lugar do acesso material e físico; (VII) promover a satisfação dos consumidores por meio de estratégias que fomentem o consumo suficiente e razoável no lugar do consumo exagerado e ostensivo; (VIII) ao invés da materialidade e da tangibilidade, assegurar valores de experiência no ato de compra; (IX) mais do que a competição empresarial, buscar a cooperação entre organizações; e, $(X)$ urgentemente, transformar a publicidade em ferramenta que não incentive o consumismo inconsciente. Salienta-se que as recomendações elencadas pelo Movimento Nacional ODS Santa Catarina tiveram por base pesquisas do Instituto Akatu acerca do consumo sustentável (BERGMANN, 2019).

Vale ressaltar que o ODS 12 apresenta diretrizes para o ano de 2030 que ultrapassam as questões do consumo e da produção sustentáveis, ainda que estas sejam seu locus de ocupação dentre os objetivos da Agenda 2030. O Quadro 1, a seguir, apresenta tais diretrizes na visão do Instituto de Pesquisa Econômica Aplicada (IPEA, 2019).

\begin{tabular}{|c|c|}
\hline Diretriz A & $\begin{array}{l}\text { Implementar um plano decenal para progra- } \\
\text { mas sobre consumo e produção sustentáveis, } \\
\text { com medidas globais, sob a liderança dos } \\
\text { países desenvolvidos e tendo em conta a } \\
\text { capacidade dos países em desenvolvimento. }\end{array}$ \\
\hline Diretriz B & $\begin{array}{l}\text { Alcançar a gestão sustentável e o uso efi- } \\
\text { ciente dos recursos naturais do globo. }\end{array}$ \\
\hline Diretriz C & $\begin{array}{l}\text { Reduzir pela metade o desperdício de alimentos } \\
\text { per capita mundial e as perdas de alimentos ao } \\
\text { longo das cadeias de produção e de abaste- } \\
\text { cimento, inclusive as perdas pós-colheita. }\end{array}$ \\
\hline Diretriz D & $\begin{array}{l}\text { Atingir o manejo ambientalmente adequado dos } \\
\text { produtos químicos e de todos os resíduos ao longo } \\
\text { do ciclo de vida destes, de acordo com os marcos } \\
\text { internacionalmente acordados, e reduzir signifi- } \\
\text { cativamente a liberação destes para o ar, água e } \\
\text { solo, buscando minimizar seus impactos negati- } \\
\text { vos sobre a saúde humana e o meio ambiente. }\end{array}$ \\
\hline Diretriz E & $\begin{array}{l}\text { Minimizar substancialmente a geração de } \\
\text { resíduos por meio da prevenção, da redução, } \\
\text { da reciclagem e do reúso de materiais. }\end{array}$ \\
\hline Diretriz F & $\begin{array}{l}\text { Incentivar as empresas, em especial, as em- } \\
\text { presas grandes e transnacionais, a adotar } \\
\text { práticas sustentáveis e a integrar informações } \\
\text { sobre sustentabilidade em seus relatórios. }\end{array}$ \\
\hline Diretriz G & $\begin{array}{l}\text { Promover práticas de compras públi- } \\
\text { cas sustentáveis, de acordo com as po- } \\
\text { líticas e as prioridades nacionais. }\end{array}$ \\
\hline Diretriz H & $\begin{array}{l}\text { Garantir que as pessoas, em todos os luga- } \\
\text { res, tenham informação relevante sobre o } \\
\text { desenvolvimento sustentável e sobre estilos } \\
\text { de vida em harmonia com a natureza. }\end{array}$ \\
\hline Diretriz I & $\begin{array}{l}\text { Apoiar países em desenvolvimento para } \\
\text { que fortaleçam suas capacidades cientí- } \\
\text { ficas e tecnológicas rumo a padrões mais } \\
\text { sustentáveis de produção e consumo. }\end{array}$ \\
\hline Diretriz J & $\begin{array}{l}\text { Desenvolver e implementar ferramentas } \\
\text { para monitorar os impactos do desenvol- } \\
\text { vimento sustentável para o turismo local, } \\
\text { que gera empregos e promove a cultura. }\end{array}$ \\
\hline Diretriz K & $\begin{array}{l}\text { Racionalizar subsídios ineficientes aos com- } \\
\text { bustíveis fósseis, que encorajam o consumo } \\
\text { exagerado, e eliminar as distorções de mercado, } \\
\text { de acordo com as circunstâncias nacionais. }\end{array}$ \\
\hline
\end{tabular}

Quadro 1: Diretrizes para 2030 do ODS 12 — Consumo e produção sustentáveis Fonte: adaptado de IPEA (2019).

Por meio do Quadro 1, faz-se possível compreender que o ODS 12 aborda a sustentabilidade por diversos ângulos, ainda que seu ponto de partida esteja calcado no consumo e na produção de bens materiais. Em específico, pode-se denotar que há nas diretrizes para 2030 oportunidades de intersecção entre o desenvolvimento sustentável e a Moda. A seguir, este assunto será explorado por intermédio do consumo sustentável. 


\section{MODA E CONSUMO SUSTENTÁVEL}

A dinâmica entre os negócios de Moda e o seu público-alvo, consumidores detentores de motivações diversas e desejos próprios, delineia a relação pessoa-objeto do sujeito contemporâneo. Presente na investigação do processo de consumo, tal relação influencia os mecanismos pertencentes à Moda, como o fenômeno social da adoção de tendências e a exteriorização da personalidade dos consumidores que, ainda que inconscientemente, comunicam-se mediante escolhas diárias sobre o vestuário e a aparência. Para Miranda (2008), por meio dessas escolhas o sujeito forma estratégias de diferenciação ou de semeIhança perante os grupos em que transita.

Segundo Solomon (2011), uma vez que a Moda e o consumo integram o sistema econômico, pode-se vislumbrá-los, também, como engrenagens centrais que regem as sociedades ocidentais e modernas. Consequentemente, compreender a relação pessoa-objeto torna-se inseparável no equacionamento das escolhas diárias dos sujeitos no ato de compra. Entender as motivações que os induzem ao consumo, a preferência por um ou outro produto e o encadeamento lógico (ou não) da transferência dos valores intangíveis dos produtos para os atributos físicos de seus consumidores torna-se, portanto, fundamental para acionar comportamentos pró-sustentabilidade em negócios de Moda.

Assim como tantas outras empresas na contemporaneidade, os negócios de Moda tornaram-se fenômenos sociais e passaram a embutir, desde a Revolução Industrial, funções simbólicas aos artefatos físicos que, por sua vez, deixaram o locus funcional para assumir características estético-formais portadoras de significados. Na década de 1950, sob influência da estratégia American Way of Life (estilo de vida americano, em livre tradução), o consumo antes ponderado e módico da nação estadunidense, formada por trabalhadores que tinham por hábito coser seus próprios trajes, passou a ser impregnado por uma nova ideologia que associava consumo e felicidade. Ao apelar para os desejos inconfessáveis daqueles trabalhadores, essa nova ideologia de expansão comercial inaugurava uma sociedade de consumidores que, além de relacionar bem-estar emocional ao ato de compra, estavam prontos para creditar aos bens materiais significados civilizatórios (GONÇALVES-DIAS; MOURA, 2007).

Diante da configuração do consumo civilizatório, a partir da década de 1960 muitas empresas passaram a projetar sua solidez no relacionamento com seus consumidores. Novas estruturas eram exigidas por um mercado formado e dirigido pela cultura jovem e pelo comportamento tribal, que marcariam as próximas décadas por meio de escolhas referentes ao vestuário e ao gosto musical. Para criar vínculos com seus consumidores mais novos, os negócios de Moda apostavam em peças de vestuário e acessórios que pudessem demonstrar, materialmente, a personalidade daqueles sujeitos e a que grupo pertenciam (BRAGA, 2007). Conforme Haug e Busch (2015), nesse momento a Moda passa a ser instrumento definitivo da cultura jovem para transmitir mensagens que, diferente do status outrora comunicado, não se encontram mais ligadas à diferença de classes: o objetivo está em acentuar a individualidade.

Desde então, tornou-se impensável a oferta de peças de vestuário e acessórios que possuam apenas funções utilitárias. Ainda que, em parte, a Indústria Têxtil e de Confecção possa produzir engodo no lugar de inovação, a materialidade no campo da Moda está vinculada à satisfação das múltiplas necessidades dos sujeitos, sejam essas de ordem psicológica ou fisiológica. Não há mais uma percepção unidimensional por parte dos consumidores. O que se observa, mesmo empiricamente, é a indissociabilidade entre a forma e a função estética — entendida, aqui, como a inteligência multissensorial dos sujeitos que captura mais dos objetos do que os registros fornecidos por seus sentidos imediatos.

Nesse sentido, conforme sublinha Lipovetsky (2009), os aspectos estético-formais exercem influência no ato de compra, tanto quanto as características funcionais que, possivelmente, serão percebidas apenas ao longo do período de uso da peça. Isto implica dizer que a função estética se constitui imediatamente quando o sujeito consome. Tal função, por seu caráter simbólico, recorre a associações com a memória, com a imaginação e com a fantasia da psiquê do consumidor, assim como desperta informações em alusão aos aspectos sociais do uso. Lipovetsky (2009) afirma que a função simbólica se materializa nos atributos estéticos dos objetos e, portanto, manifesta-se, de modo eficaz, quando a aparência é capturada sensorialmente e associada com os pensamentos do sujeito.

Conforme aponta Miranda (2008), o consumo pode ser compreendido como o modus concreto e visível da construção das identidades dos sujeitos contemporâneos. Isto implica entendê-lo como um processo cultural ativo, ou seja, uma forma direta e completa de comunicação que transcende a aquisição de bens materiais por si só. A autora destaca que, nessa perspectiva, o ser humano se torna o que consome. De modo a corroborar com Miranda (2008), aponta-se a compreensão de Lipovetsky (2009) que defende a ideia do ato consumidor como parte de um ensejo 
individual de escalada social e como exercício estético pessoal. Para Morelli (2018, p. 135), este é um campo fértil para a expansão da dinâmica da Moda que, cada vez mais,

[...] não se dará mais apenas pela busca de solucionar necessidades físicas, mas, principalmente, [pelas] necessidades simbólicas. A dinâmica da moda promove uma busca constante de atualização da aparência, incentivando o consumo desregrado de novos produtos. Inicialmente concentrada no vestuário, essa dinâmica ultrapassa as fronteiras do vestir para manifestar-se em todo tipo de objeto [...].

Na concepção de Morelli (2018), ao transpor o vestuário, a Moda reconfigura os signos da relação pessoa-objeto de outras materialidades. Lipovetsky (2009, p. 199) cita que "[...] jamais se consome um objeto por ele mesmo ou por seu valor de uso, mas em razão de seu 'valor de troca de signo' [...]". Isto implica dizer que o consumo pode pautar-se nas acepções individuais e coletivas do prestígio, do status e do reconhecimento da posição social que o objeto consumido apresenta e reapresenta na dinâmica da Moda. Miranda (2008) ressalta que o valor de troca existente na relação pessoa-objeto sublinha o caráter decisório envolvido no ato de compra e no processo de escolha de uma marca. Para os autores, tal processo carrega em si um volume altíssimo de significados que ultrapassam a dimensão econômica do objeto e o levam a ocupar um papel de destaque no contexto social, o que faz com que a importância das marcas transponha o limite das materialidades, perceptíveis sensorialmente, e invada a vida privada dos sujeitos.

Nessa perspectiva, Kotler, Kartajaya e Setiawan (2010) apontam para as marcas como elementos que interagem e se inserem de forma cada vez mais profunda na rotina dos consumidores. Os laços afetivos e os relacionamentos criados em cada ato de compra no cotidiano ajudam a explicar as preferências dos consumidores, e podem ser utilizados, não raro, como fonte para decisões estratégicas acerca dos negócios de Moda. Além de buscar capilarizar sua influência e atrair novos consumidores, essas empresas também ensejam fidelizar aqueles já conquistados. Nesse sentido, para os autores, as marcas contemporâneas precisam de mudanças estruturais de modo a tornarem-se capazes de se adaptar à dinâmica do mercado atual e às necessidades de seus consumidores, estejam eles já fidelizados ou ainda em fase de prospecção.

Kotler, Kartajaya e Setiawan (2010) ressaltam que, entre as necessidades de consumo mais expressivas nas últimas décadas, está a sustentabilidade. Essa demanda, proveniente do aumento do critério em relação à responsabilidade socioambiental das empresas, força o consumo civilizatório e fundamentalmente simbólico a converter seus aspectos culturais para atender a um novo estado, classificado, então, como consumo consciente. Morgenstern e Witkoski (2018, p. 72) confirmam a observação realizada pelos autores supramencionados ao asseverarem que "[...] tendências revelam um consumidor voltado ao consumo consciente, mais envolvido em práticas sustentáveis e sociais [...]". Para Haug e Busch (2015), é no consumo consciente que os sujeitos se abstêm de práticas prejudiciais a outras pessoas, aos animais ou ao meio ambiente para, em contrapartida, exercitar o comportamento pró-sustentabilidade. Os autores acreditam que, como desdobramento do consumo consciente, surgiram questões como a ecomoda e o consumo ético, assuntos que serão abordados a seguir.

\subsection{Ecomoda e Consumo ético}

Haug e Busch (2015), Schulte (2015) e Morelli (2018) sinalizam que a ecomoda - ou "moda verde" — pode ser compreendida enquanto parte do consumo ético. Para todos os autores, se houver uma disseminação eficiente dos pilares do desenvolvimento sustentável, tal qual preconiza a ONU por intermédio dos ODS, a ecomoda poderá deixar de ser considerada um exemplo de tendência de longo prazo e passará, concretamente, a ser estimada na criação de políticas públicas, no comprometimento socioambiental das empresas e nos acordos entre a Indústria Têxtil e de Confecção e o governo, tanto em âmbito local quanto no panorama global.

Para aumentar a parcela de consumidores éticos e adeptos à ecomoda, Haug e Busch (2015) destacam que, como sociedade, é preciso que todos os sujeitos transcendam os hábitos de compra tradicionais e conscientizem-se sobre o potencial de produtos pró-sustentabilidade, sejam peças de vestuário ou não. Sobre as estratégias mercadológicas, os autores salientam que: (I) as marcas devem utilizar com discernimento e transparência táticas de green marketing (marketing verde); (II) a alavanca necessária para direcionar os negócios de Moda no sentido de uma transição em direção à ética deve considerar o poder dos consumidores; e que (III) é necessário definir um painel com as expectativas dos consumidores, sua capacidade de investimento e de assimilação das informações pró-ambientais, bem como, seu comportamento de compra mediante a possibilidade de escolha entre produtos éticos e não éticos.

Miranda (2008) reitera que, por seu espectro simbólico, a relação pessoa-objeto caracteriza-se como significadora de costumes sociais e culturais que estão expressos nos 
diversos papéis que os sujeitos desempenham nas inúmeras interações com os grupos percorridos em seu cotidiano. Isto implica dizer que, no tangente aos produtos éticos e não éticos, também a relação pessoa-objeto passa a ser moldada em conformidade à personalidade assumida pelos sujeitos diante de seus grupos, o que pode validar ou refutar o discurso pró-sustentabilidade da ecomoda. Ou seja, dependendo do grupo em que se encontram, os consumidores podem utilizar da relação supracitada para exprimir pertencimento ou distanciamento.

Para compreender a dinâmica dos consumidores em transição, que ora podem apresentar-se inclinados ao consumo ético e à ecomoda, ora não, Fajardo (2010) afirma que as empresas devem alinhar-se, estruturalmente, às mudanças urgentes em direção à eficiência de seus processos produtivos, desde a coleta de insumos até a entrega para os consumidores. Com isto, as empresas podem responder de modo rápido e de maneira assertiva aos desejos dos consumidores éticos ou não éticos. $O$ autor acrescenta que o processo de adaptação ao volátil mercado atual deve estar em pauta nas decisões estratégicas de líderes da Indústria Têxtil e de Confecção.

Fajardo (2010) cita o consumo ético como tendência de consumo voltada à sustentabilidade, diferentemente dos autores expostos anteriormente, que visualizam uma transição em curso entre o consumo civilizatório e o consumo ético, perpassado pelo consumo consciente. Segundo o autor, a tendência trata da redução dos danos provocados pelos diversos negócios de Moda e do incentivo para uma produção mais responsável do que a tradicionalmente realizada nas indústrias em questão. Fajardo (2010) assinala que, mediante os preceitos da ecomoda, os prejuízos causados aos recursos do planeta devem ser esclarecidos em todos os nós da cadeia produtiva e de consumo de Moda.

Do mesmo modo que Miranda (2008), Fajardo (2010) aponta que o consumidor ético pode ser visualizado como um potencial investidor em produtos que, simbolicamente, compartilham de valores entendidos como importantes por estes sujeitos e seus grupos. Para o autor, tais valores estão calcados no bem-estar coletivo, na preservação dos recursos naturais, na remuneração justa dos trabalhadores, na disseminação de atitudes que incitam o cuidado com o meio ambiente e com as comunidades locais e, por fim, na crença de um desenvolvimento sustentável e econômico com ênfase na dignidade humana por parte da sociedade e das empresas.

Importa ressaltar que as preocupações sociais, ambientais e econômicas não podem ser compreendidas como recentes. Braga (2007) afirma que, já no final da primeira metade do século XX, era possível vislumbrar os sintomas incipientes dos efeitos colaterais resultantes de um crescimento econômico global que ignorou a existência de limites na utilização de recursos naturais não renováveis. Alterações climáticas, contaminação do ar, do solo e da água e esgotamento de insumos provenientes do meio ambiente despertavam a atenção de cidadãos ambientalistas, ainda que pouco preocupassem as empresas produtoras de bens materiais da época.

Para Zanirato e Rotondário (2016), com a aceleração do consumo a partir da década de 1950, houve um aumento significativo da produção de bens materiais e da demanda que subestimavam a escassez dos recursos planetários e eram indiferentes à assimilação dos resíduos gerados durante o processo produtivo. Esse crescimento desenfreado fez emergir reflexões acerca da finitude dos recursos naturais. Na década de 1970, as discussões antes atreladas aos grupos de estudiosos do meio ambiente passaram para a rotina de alguns grupos de consumidores jovens, ainda que muito timidamente. A transposição das discussões pró-ambientais para a mesa do cidadão comum foi incentivada pelo comportamento romantizado e revolucionário que contagiava a camaradagem da juventude setentista.

Para Lima et al. (2018), neste momento da história o consumo inclinou-se para as questões socioambientais até outrora ignoradas, contudo, foi apenas vinte anos depois, na década de 1990, que as reflexões acerca da degradação do planeta passaram a dialogar com a Moda. Braga (2007, p. 102) menciona que,

A preocupação ecológica também esteve presente na moda dos anos de 1990, e essa conscientização se refletiu em muitas coleções de estilistas renomados, que denunciavam as agressões ao planeta Terra nas criações de suas roupas. Foi a moda fazendo-se presente, atualizada e notada no contexto mundial.

Tais estilistas podem ser ilustrados pelos britânicos Alexander McQueen (1969-2010), John Galliano (1960atual), Stella McCartney (1971-atual) e Zandra Rhodes (1940-atual), entre outros. Para McCraken (2003), há uma explicação para tantos exemplos ingleses: a Revolução do Consumo que, séculos antes, transformou a Moda e o comportamento mediante a cultura nacional.

\subsection{A Revolução do Consumo e seu desdobra- mento no comportamento do consumidor}

Segundo aponta McCraken (2003), a Revolução do Consumo provocou mudanças no gosto e nos costumes dos sujeitos do século XVI, especialmente, na Inglaterra (UK) e na França 
(FR). Além de alterar, significativamente, a vida dos consumidores e os meios de produção nacionais, a Revolução do Consumo instaurou uma nova cultura com base na consagração da materialidade e em seu simbolismo.

Morgenstern e Witkoski (2018) afirmam que nesse processo o consumo tornou-se consumismo. Para as autoras, apesar de próximos, esses termos caracterizam fenômenos diferentes:

O consumo é caracterizado pela compra que atende às necessidades básicas, ou seja, essenciais para o bem-estar da sociedade, como alimento, vestimenta, moradia, transporte, segurança, lazer, entre outros. O consumismo, que caracteriza a sociedade atual, parte do pressuposto de satisfazer a desejos moldados por questões culturais, ambientais ou de marketing, atendendo a um significado simbólico, refletindo em contextos éticos, econômicos e ambientais (MORGENSTERN; WITKOSKI, 2018, p. 69).

Essa revolução no modo de consumir não mudou apenas conceitos ocidentais de tempo, espaço, sociedade, indivíduo, família e Estado. Ela moldou, também, a psiquê do sujeito, que passou a depender da materialidade para se expressar como indivíduo e para ser legitimado como pertencente a um grupo em especial. A indissociabilidade entre os novos bens materiais, produzidos ferozmente nas fornalhas industriais da época, e os consumidores citadinos, já amolados no consumo simbólico, impulsionavam o crescimento econômico irrefreável das nações supracitadas e transformavam cidadãos comuns em agentes sociais do consumismo (MCCRACKEN, 2003; MORGENSTERN; WITKOSKI, 2018).

Para Sant'Anna (2016) surgiu, então, a ideia de um narcisismo coletivo que se infiltrava facilmente na sociedade e que se intensificava na dimensão estética do vestuário, que visava promover uma paixão pela forma. Essa obsessão estética tornou-se possível pelo mundo dos símbolos que, por sua vez, disseminava estruturas preconcebidas acerca da cultura e do ideário nacionalistas. Ainda que empregassem diferentes interpretações e utilizassem de diversificadas manifestações simbólicas, os sujeitos se conectavam, inconscientemente, pelos símbolos que compartilhavam e que reconheciam nos objetos e uns nos outros. Tais símbolos lubrificavam a relação de aceitação ou de recusa dos sujeitos mediante o contexto coletivo. De modo análogo, os consumidores contemporâneos conectam-se aos objetos por meio da comunicação e das mídias, que se valem dos símbolos para, em uma vitrine sem limites geográficos, propor a sobreposição da sociedade imagética à sociedade do trabalho.
O significado simbólico dos objetos na sociedade imagética foi descrito por Sant'Anna (2016) como a materialização do ato de consumo e como constituinte da irracionalidade consumida, dificilmente explicada pela lógica. As emoções, as aspirações do ser e os desejos inconfessáveis dos sujeitos, tal qual citam Gonçalves-Dias e Moura (2007), subjugam as regras matemáticas dos relatórios de vendas e criam demandas infinitas, pessoais e identitárias. Para Sant'Anna (2016), o consumo consiste na oportunidade dos sujeitos de construírem autobiografias por meio de suas posses e está ligado à autoexpressão e às noções do gosto. Portanto, ressalta a autora, a aparência torna-se o fio condutor da produção das identidades diante dos olhos de expectadores anônimos, e o vestuário, ferramenta de tradução das múltiplas personalidades dos sujeitos, converte-se em instrumento de poder apto ao uso na composição das identidades e na transferência dos atributos do que é consumido para as habilidades de quem o consome.

Segundo McCracken (2003), como desdobramento da Revolução do Consumo, o vestuário passou a evidenciar categorias e princípios culturais, fossem eles temáticos ou de ordem relacional, além de bases reais ou imaginárias pertencentes a um grupo ou a uma forma de expressão em si. Destaca-se que, no vestuário, as categorias e os princípios culturais podem ser codificados e se manifestarem por meio de engrenagens diacrônicas, dúbias e, às vezes, conflitantes. Nesse sentido, o autor afirma que,

O vestuário desempenha seu papel diacrônico de várias maneiras. Uma de suas principais manifestações enquanto reflexo e agente de mudança é o fenômeno da moda [...] O vestuário às vezes é a confirmação da mudança e, às vezes aquilo que dá início a ela. Algumas vezes é um meio de constituir a natureza e os termos de um conflito político; outras, um meio de criar consenso. Algumas vezes é instrumento de uma tentativa de dominação; outras, o arsenal da resistência e do processo [...] Em seu papel diacrônico, o vestuário funciona como um mecanismo comunicativo por meio do qual a mudança social é contemplada, proposta, iniciada, reforçada e negada. Seu estudo nos permite observar o aspecto expressivo da cultura material sob uma de suas formas mais radicalmente criativas (MCCRACKEN, 2003, p. 222-223).

A compreensão de McCraken (2003) sobre o vestuário pode ser aplicada ao comportamento do consumidor descrito por Solomon (2011). Em sua obra O comportamento 
do consumidor: comprando, possuindo e sendo, Solomon (2011) salienta o vestuário como mecanismo de ajuste do sujeito ao contexto coletivo e cultural no qual se encontra alocado. Para o autor, estudar o comportamento do consumidor significa estudar a relação entre as pessoas e os produtos que as ajudam a moldar suas identidades diariamente. Perceber de que forma o ter ou não ter afeta a vida de um sujeito, ou seja, como a relação pessoa-objeto influencia diretamente a forma como o indivíduo se sente sobre ele mesmo e o mundo ao seu redor, é entender que: [...] o comportamento do consumidor é mais do que comprar coisas; também abrange o estudo de como o fato de possuir (ou não) certas coisas, afeta nossas vidas e como nossas posses influenciam a maneira como nos sentimos a respeito de nós mesmos e dos outros - nosso estado de ser (SOLOMON, 2011, p. 13).

Solomon (2011, p. 33) acrescenta que o comportamento do consumidor pode ser assimilado como uma forma de estudar os motivos pelos quais "[...] indivíduos ou grupos selecionam, compram, usam ou descartam produtos, serviços, ideias ou experiências para satisfazer necessidades e desejos". Nessa perspectiva, o autor cita que o processo de consumo envolve diversos atores, tais como compradores, usuários, influenciadores e sabotadores, que podem cambiar de função, especialmente, quando os consumidores estão inseridos em grupos, tal qual ocorre em núcleos familiares ou em círculos de amizade. $\mathrm{O}$ autor afirma ser comum que, em tais situações, o processo decisório não esteja concentrado em apenas um sujeito, o que pode tornar difícil a categorização de arquétipos acerca dos papéis desses atores.

O empecilho ao qual se refere Solomon (2011) está em encaixar os consumidores em um único e hermético perfil e, consequentemente, ignorar sua transitoriedade. Como resposta, o autor sugere o estudo do comportamento do consumidor sob as seguintes perspectivas: (I) idade; (II) gênero; (III) estrutura familiar; (IV) classe social e renda; (V) raça e etnicidade; (VI) geografia; e (VII) estilos de vida (Quadro 2).

\begin{tabular}{|l|l|}
\hline Perspectiva & Variáveis analisadas \\
\hline Idade & $\begin{array}{l}\text { Conjunto de valores e experiências culturais: } \\
\text { apesar das diferenças entre consumidores de uma } \\
\text { mesma faixa etária serem significativas, alguns } \\
\text { conjuntos de valores e de experiências culturais } \\
\text { são compartilhados e mantidos ao longo da } \\
\text { vida. Estes conjuntos devem ser analisados. }\end{array}$ \\
\hline Gênero & $\begin{array}{l}\text { Diferenciação por gênero: nesta variável, são } \\
\text { analisados os produtos posicionados como sendo } \\
\text { exclusivamente para homens ou para mulheres. }\end{array}$ \\
\hline
\end{tabular}

\begin{tabular}{|l|l|}
\hline $\begin{array}{l}\text { Estrutura } \\
\text { Familiar }\end{array}$ & $\begin{array}{l}\text { Estado civil e dependentes: a família e o es- } \\
\text { tado civil de um consumidor são duas vari- } \\
\text { áveis demográficas extremamente impor- } \\
\text { tantes e que afetam diretamente a maneira } \\
\text { como os sujeitos priorizam seus gastos. }\end{array}$ \\
\hline $\begin{array}{l}\text { Slasse } \\
\text { Recial e }\end{array}$ & $\begin{array}{l}\text { Recursos financeiros e posição social: a segmentação } \\
\text { por classe social procura englobar pessoas que com- } \\
\text { partilham a mesma faixa de renda e posição social, e } \\
\text { entender como a distribuição da riqueza se dá para de- } \\
\text { terminar o poder de compra e a potência de mercado. }\end{array}$ \\
\hline $\begin{array}{l}\text { Raça e } \\
\text { Etnicidade }\end{array}$ & $\begin{array}{l}\text { Diversidade cultural e étnica: faz-se impor- } \\
\text { tante analisar como variáveis do consumo a } \\
\text { pluralidade cultural e étnica dos grupos aos } \\
\text { quais estão sujeitos os consumidores. }\end{array}$ \\
\hline Geografia & $\begin{array}{l}\text { Localização: ofertas de um local especí- } \\
\text { fico podem influenciar o consumo. }\end{array}$ \\
\hline $\begin{array}{l}\text { Estilos } \\
\text { de vida }\end{array}$ & $\begin{array}{l}\text { Lifestyle (estilo de vida): mesmo que compartilhem } \\
\text { variáveis demográficas, os consumidores têm estilos } \\
\text { de vida diferentes e o modo como um sujeito se } \\
\text { sente sobre ele mesmo, seus hobbies, aspirações e } \\
\text { desejos, são fatores que ajudam a determinar sua } \\
\text { forma de comportar-se em relação ao consumo. }\end{array}$ \\
\hline
\end{tabular}

Quadro 2: Variáveis de análise do comportamento do consumidor Fonte: adaptado de Solomon (2011).

A proposta de Solomon (2011) busca instituir perspectivas para analisar as variáveis do comportamento do consumidor com base em idade, gênero, estrutura familiar, classe social e renda, raça e etnicidade, localização geográfica e estilo de vida (Quadro 2). No entanto, o próprio autor afirma que podem existir outras variáveis, mais sutis ou subjetivas que aquelas listadas, relacionadas com características íntimas e particulares dos sujeitos e, muitas vezes, imperceptíveis ao tecido social. Em verdade, Solomon (2011) denota que os gostos dos consumidores não podem ser objetivamente examinados por meio de dados estatísticos, ainda assim, tais gostos não deixam de ser extremamente relevantes para o estudo de seus comportamentos.

Solomon (2011) afirma, também, que para a completa compreensão do comportamento do consumidor é necessário elucidar a forma como as opiniões dos grupos em que o sujeito transita influenciam suas decisões de compra, sem esquecer que, mesmo que compartilhem aspectos demográficos, consumidores de um mesmo grupo podem ter imagens diferentes de si mesmos e dos objetos que consomem. Para o autor, esses fatores auxiliam na definição de como grupos respondem - com maior ou menor aceitabilidade — às propostas da materialidade. Ao estudar o comportamento de grupos de jornalistas, blogueiros e comentaristas de Moda, Matthews (2015) identificou cinco perfis de influência dentro dos grupos de consumidores: (I) o inovador, chamado de tastemaker (formador de opinião ou formador do gosto coletivo, em livre tradução); (II) o artístico; (III) o comentarista; (IV) o criador de imagens; e (V) o seletor (Quadro 3). 


\begin{tabular}{|l|l|}
\hline Perfil & Características \\
\hline Inovador & $\begin{array}{l}\text { Introduz uma nova proposta de materialida- } \\
\text { de ou altera uma proposta já estabelecida. } \\
\text { Pode indicar, fortemente, uma mu- } \\
\text { dança, um novo produto, um novo } \\
\text { processo ou um novo método. }\end{array}$ \\
\hline Artista & $\begin{array}{l}\text { Desempenha um papel ou participa } \\
\text { do entretenimento público acerca da } \\
\text { nova proposta da materialidade. } \\
\text { Realiza ou executa uma ação especí- } \\
\text { fica para auxiliar na construção do es- } \\
\text { tado da arte da proposta material. }\end{array}$ \\
\hline Comentarista & $\begin{array}{l}\text { Explica a nova proposta da materialida- } \\
\text { de para os demais membros do grupo } \\
\text { com ênfase nas características intangí- } \\
\text { veis dos objetos e em sua relação com os } \\
\text { valores compartilhados pelo grupo. }\end{array}$ \\
\hline $\begin{array}{l}\text { Criador de } \\
\text { imagem }\end{array}$ & $\begin{array}{l}\text { Cria imagens possíveis de como a proposta } \\
\text { irá ser configurada e assumida no futuro. }\end{array}$ \\
\hline Seletor & $\begin{array}{l}\text { Percebe ou reconhece a diferença en- } \\
\text { tre as diversas propostas da materia- } \\
\text { lidade e é capaz de direcioná-las para } \\
\text { os diferentes sujeitos do grupo. }\end{array}$ \\
\hline
\end{tabular}

Quadro 3: Perfis de influência nos grupos de consumidores

Fonte: adaptado de Matthews (2015).

Para Matthews (2015), é no interior dos grupos de consumidores que o gosto é construído, tanto no âmbito do coletivo, que valida o gosto particular dos tastemake$r s$, como no âmbito individual, que se apropria dos valores e dos significados creditados aos bens materiais para a elaboração de uma personalidade própria. Segundo a autora, no jogo entre a autoexpressão e o pertencimento, os formadores do gosto legitimam seu poder de discernimento dos aspectos estético-formais da materialidade e utilizam do vestuário como veículo de manifestação de seu poder.

Assim, conforme a literatura investigada, acredita-se que, como desdobramento da Revolução do Consumo, as mudanças acerca do comportamento dos sujeitos contemporâneos levaram a sociedade ao estado de consumismo. Para superá-lo, deve haver a possibilidade de se intensificar a transição do sistema baseado no consumo civilizatório e meramente simbólico para um consumo ético, liderado por escolhas pró-sustentabilidade e novas propostas de materialidades que abarquem a responsabilidade socioambiental dos negócios de Moda. Sem produzir alterações sistêmicas no comportamento, no consumo e na cultura atual, as projeções continuarão a apontar para um futuro preocupante e, por vezes, desencorajador. A seguir, apresentar-se-ão os procedimentos metodológicos utilizados para explorar o exemplo pretendido à luz do corpo de conhecimento construído neste artigo.

\section{PROCEDIMENTOS METODOLÓGICOS}

Acerca da classificação deste artigo como pesquisa, optou-se pelo enquadramento à proposta de Gil (2008) que categoriza as pesquisas científicas por meio de cinco perspectivas fundamentais: (I) do ponto de vista da finalidade da pesquisa; (II) segundo a abordagem ao problema de pesquisa; (III) quanto aos objetivos propostos pelos autores; (IV) acerca dos procedimentos técnicos empregados; e (V) mediante o local onde a pesquisa foi realizada. Seguindo tal categorização, este artigo classifica-se como: (I) pesquisa aplicada; (II) pesquisa qualitativa; (III) pesquisa descritiva; (IV) pesquisa bibliográfica; e (V) pesquisa de campo.

Sobre os procedimentos técnicos empregados neste artigo, utilizou-se de pesquisa bibliográfica narrativa com autores escolhidos por afinidade ao tema e com o objetivo de se estabelecerem as correlações necessárias à compreensão do problema de pesquisa.

Em um primeiro momento, os dados obtidos por meio do levantamento bibliográfico fundamentaram o referencial teórico sobre Moda e consumo sustentável, assim como, sobre a empresa de Florianópolis (SC). A escolha da empresa deu-se pela proximidade entre uma das autoras do artigo e a entrevistada, não tendo sido estabelecidos critérios pré-definidos de antemão. O Quadro 4 descreve tecnicamente a empresa a partir de informações disponíveis em seu endereço eletrônico.

\begin{tabular}{|l|l|}
\hline Fundação & 05/01/2017 \\
\hline $\begin{array}{l}\text { Cadastro Nacional de } \\
\text { Pessoa Jurídica (CNPJ) }\end{array}$ & 26.809.704/0001-01 \\
\hline Razão Social & Raquel Elias de Souza \\
\hline Nome Fantasia & Black Purpurin: Moda 3D \\
\hline Atividade principal & $\begin{array}{l}\text { Confecção de peças de vestuário, exce- } \\
\text { tuando-se roupas íntimas e sob medidas }\end{array}$ \\
\hline Produtos & $\begin{array}{l}\text { Máscaras antivirais, tênis, bolsas, } \\
\text { colares, alças e porta-celulares }\end{array}$ \\
\hline Preços praticados & Entre R\$ 169,00 e R\$ 4.000,00 \\
\hline Endereço & $\begin{array}{l}\text { Rua Delminda Silveira, 827, sala 401, } \\
\text { bairro Agronômica, Florianópolis (SC) }\end{array}$ \\
\hline
\end{tabular}

Quadro 4: Descrição técnica da empresa selecionada para a pesquisa Fonte: Loja Black Purpurin (2020).

Em um segundo momento, a coleta de dados ocorreu por meio de entrevista realizada no dia 04 de março de 2020, com Raquel Souza, coproprietária da Black Purpurin. A entrevista foi realizada por Paula Martin em uma unidade da empresa, a saber: Rua dos Chernes, número 60, Loja 6 , bairro de Jurerê, cidade de Florianópolis (SC). Para a entrevista foi construído um roteiro com vinte perguntas que abordaram o consumo sustentável e o histórico da empresa: 
1) Como a marca Black Purpurin surgiu?;

2) Qual o processo produtivo da Black Purpurin? Ele emprega algum tipo de tecnologia ou materiais voltados para estratégias pró-sustentabilidade?;

3) Quais são os insumos utilizados no processo produtivo?;

4) Você poderia me contar um pouco mais sobre a fabricação dos produtos no início da marca: os testes com a impressão 3D, as limitações técnicas, os tipos de materiais utilizados e por que foi feita a substituição desses materiais?;

5) Como é a imagem de marca que a Black Purpurin gostaria que fosse formada por seus consumidores?;

6) Foi utilizado algum dos Objetivos de Desenvolvimento Sustentável das Nações Unidas como princípio fundamentador da Black Purpurin?;

7) Por que a Black Purpurin declara que seus produtos são $90 \%$ sustentáveis?;

8) A empresa adota transparência quanto aos seus fornecedores?;

9) A montagem dos produtos é feita à mão ou vocês procuram investir em algum tipo de mão de obra específica?;

10) A forma como o processo produtivo da marca se desenvolveu agrega mais valor ao produto e cria um valor simbólico maior para a sua marca?;

11) A Black Purpurin recebeu o prêmio de inovação na categoria Empresa Referência de Economia Criativa do Ecossistema, qual foi o impacto de receber essa premiação para a marca? Quais os fatores de vantagem competitiva que a empresa tem para ter recebido o prêmio?;

12) A Black Purpurin se considera um negócio de alto impacto? Por que?;

13) O consumidor da marca Black Purpurin é um consumidor aberto às questões que envolvem o tema sustentabilidade? A marca acredita que a sustentabilidade do produto é um fator decisivo na hora da escolha do seu consumidor? Por que?;

14) O processo produtivo dos produtos da Black Purpurin impacta no marketing da empresa?;

15) Quais os fatores mais importantes que a Black Purpurin leva em consideração em suas decisões de marketing?;

16) Como o consumidor da Black Purpurin compreende a relação entre as empresas de moda e a escassez dos recursos naturais? A marca acredita que os consumidores têm essa consciência?;

17) Qual a maior dificuldade em trabalhar em um mercado como o brasileiro, no qual segundo o Instituto
Akatu, a sustentabilidade não está entre os fatores que mais influenciam o consumidor na hora da compra?;

18) Qual o perfil do consumidor da Black Purpurin?;

19) Quais as maiores dificuldades em produzir de maneira sustentável no Brasil em termos de matéria-prima?;

20) O que a Black Purpurin vê como crucial na hora do processo de escolha do seu produto por seus clientes?

Após a entrevista e sua respectiva transcrição textual procedeu-se a análise dos dados obtidos por meio das respostas coletadas. Por se tratar de uma pesquisa qualitativa, a análise dos dados aconteceu de modo interpretativo. Logo, a partir da literatura investigada e de recortes da entrevista realizada, apresenta-se a seguir o exemplo florianopolitano da empresa Black Purpurin.

\section{UM EXEMPLO DE FLORIANÓPOLIS (SC)}

Segundo os apontamentos de Schulte (2015), pequenas empresas desempenham um papel fundamental na evolução da compreensão acerca da sustentabilidade ao redor de todo o globo, pois disseminam e capilarizam novos comportamentos de consumo. Nessa perspectiva, insere-se o exemplo da empresa Black Purpurin, de Florianópolis (SC), cujo foco de atuação está na confecção de bolsas e de acessórios. Segundo consulta ao endereço eletrônico do Projeto Draft (MARASCIULO, 2020), a trajetória da marca possui momentos de produção artesanal, testes com diferentes impressoras 3D e, por fim, validação diante do cenário nacional da Moda.

Em 2017, o casal Juliano Mazute e Raquel Souza criou a marca de acessórios e bolsas Black Purpurin com foco em produzir peças para o mercado local a partir de processos de impressão 3D que, por sua vez, utilizavam materiais recicláveis (MARASCIULO, 2020). Segundo a entrevistada (Pergunta 1), o primeiro protótipo de bolsa foi feito, propriamente, com uma caixa de leite. Após testar a comercialização de suas primeiras bolsas por meio da loja de uma pessoa de seu círculo de amizades e obter êxito, a entrevistada afirma ter buscado apoio na então empresa de seu cônjuge (o nome da empresa não foi mencionado), em São Paulo (SP), que já trabalhava com impressão em 3D. Apesar da evidente intenção pró-sustentabilidade, quando questionada sobre se a marca surgiu fundamentada em algum dos ODS, a entrevistada tangenciou o assunto (Pergunta 6).

Inicialmente as peças da marca foram comercializadas em uma loja no centro da cidade de Florianópolis (SC) com um target (preço médio) de $\mathrm{R} \$ 180,00$ (cento e oitenta reais). Em média, na época, eram produzidas e vendidas 30 peças por mês. Em um segundo momento, ainda no ano de 2017, os proprietários começaram a realizar os primeiros 
testes com as impressoras 3D. Foram registradas limitações técnicas relacionadas ao tipo de material empregado, um bioplástico rígido que pouco permitia a criação artística dos proprietários e que custava R\$ 350,00 (trezentos e cinquenta reais) por quilograma ( $\mathrm{kg}$ ); e ao espaço físico disponível para a mesa de impressão (MARASCIULO, 2020). A entrevistada relata que, nessa época, era comum levar choques na impressora que, não raro, acabava por incendiar-se devido aos problemas com a matéria-prima e com os ajustes de suas configurações (Pergunta 4).

Depois de seis meses de testes, Raquel Souza conseguiu produzir a primeira bolsa oficial da marca. Nove peças compuseram a primeira coleção, lançada no ano de 2018 e com um target de $\mathrm{R} \$$ 300,00 (trezentos reais). Nesse tempo, produzir uma única peça consumia três dias de trabalho. Com a venda da coleção, foi possível investir na produção de novos modelos, que passaram a demandar menos tempo e mais criatividade. Para tornar o processo produtivo dinâmico, novas máquinas e novos insumos passaram a ser testados. Com a contratação de um designer e de dois auxiliares, o investimento atingiu o montante de $\mathrm{R} \$ 110.000,00$ (cento e dez mil reais). Como retorno, o processo que antes levava três dias, passou a ser realizado em seis horas e o número de modelos cresceu para 30 - o que possibilitou o lançamento oficial da marca em dezembro de 2018, na oportunidade da criação de um endereço eletrônico que alocava o e-commerce (comércio eletrônico) próprio da Black Purpurin (MARASCIULO, 2020).

Além do e-commerce, a marca estabeleceu uma loja física na região central da cidade de Florianópolis (SC), onde permaneceu até meados de 2019. Em fevereiro daquele ano, a marca recebeu um investimento de $\mathrm{R} \$$ 150.000,00 (cento e cinquenta mil reais) e, cerca de um mês depois, foi acelerada pela empresa Pluris, que possibilitou sua estruturação formal (MARASCIULO, 2020).

O terceiro momento da história da marca ocorreu mediante sua validação no cenário nacional. Com o auxílio do Serviço Brasileiro de Apoio às Micro e Pequenas Empresas de Santa Catarina (Sebrae/SC), a marca foi convidada a expor suas peças durante o São Paulo Fashion Week (SPFW) número 47, que ocorreu de 22 até 27 de abril de 2019. Na oportunidade, Raquel Souza palestrou no evento sobre inovação no campo da Moda, o que ajudou a dar visibilidade para a marca no contexto brasileiro.

Ainda no ano de 2019, a Black Purpurin foi premiada pela Fundação Centros de Referência em Tecnologias Inovadoras (CERTI), de Florianópolis (SC), como empresa referência de Economia Criativa no ecossistema local. A
Fundação CERTI consiste em uma organização independente e sem fins lucrativos voltada para a busca de soluções inovadoras no âmbito da iniciativa privada, do governo e do terceiro setor (TROMBINI, 2019). Sobre o assunto (Pergunta 11), a entrevistada afirma ter sido surpreendida pelo prêmio, pois acreditava que este seria direcionado, tão somente, às empresas de médio e de grande porte.

Em fevereiro de 2020, a Black Purpurin inaugurou uma flagship store (loja conceito) no bairro de Jurerê, em Florianópolis (SC) (Figura 1). Ao Portal do Projeto Draft (MARASCIULO, 2020), os proprietários da marca relataram que a loja tem o objetivo de aproximar tecnologia e experiência de consumo, uma vez que parte do processo produtivo pode ser visualizada, in loco, pelos consumidores da marca.

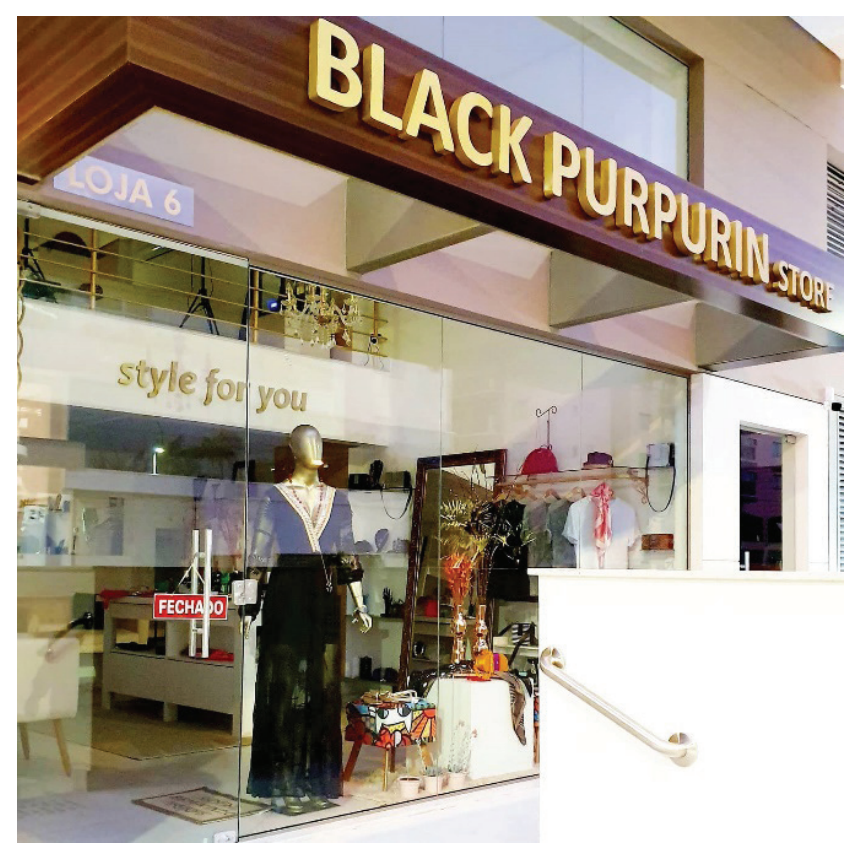

Figura 1: Flagship store Black Purpurin Fonte: Loja Black Purpurin (2020).

Em seu processo produtivo, a entrevistada acredita que a Black Purpurin agrega diferencial competitivo por meio de inovação tecnológica e de pesquisa em matérias-primas ecologicamente eficientes (Pergunta 3). Sobre a manufatura de suas criações, a entrevistada afirmou que (Pergunta 2),

\begin{abstract}
O processo produtivo começa no croqui, a gente faz primeiro o desenho à mão, depois vai para o software. A gente passa por três softwares, primeiro, o CAD, CAM e CODIGO, para os ajustes finais e depois vai para impressão, e quando vai para impressão, no caso, já sai a peça pronta.
\end{abstract}

Para que as peças possam sair prontas da impressão, atualmente, utilizam-se como matérias-primas na empresa (Pergunta 3): (I) o poliácido láctico (PLA), um polímero 
orgânico de origem biológica e proveniente de recursos renováveis; e (II) o polietileno tereftalato de etileno glicol (PETG), um termoplástico versátil que se assemelha ao politereftalato de etila (PET), isto é, ao plástico convencional. A entrevistada cita que o PLA empregado pela Black Purpurin advêm do milho e da casca da mandioca, enquanto o PETG é proveniente da reciclagem do lixo plástico e pode ser desmanchado, no futuro, para ser reaproveitado como insumo novamente. Como limitação ao uso de tais materiais, a entrevistada cita as opções de cores, que são poucas e que, devido ao desejo de permanecer como empresa pró-sustentabilidade, não são empregados corantes de quaisquer origens nos produtos confeccionados (Perguntas 4 e 19).

Como acabamento, a entrevistada menciona que utiliza aviamentos metálicos antialérgicos - que podem ser desmontados e reaproveitados - e partes de couro sintético (Pergunta 7). Durante a entrevista, ela demonstrou interesse em, futuramente, utilizar o couro da casca do abacaxi (Pergunta 17).

Ainda sobre o processo produtivo, a entrevistada afirma que, hoje, o tempo para impressão dos produtos é de quatro até seis horas, a depender do modelo. Soma-se, a isto, a montagem manual, que toma mais uma hora, em média. ver um design minimalista que possa diminuir tal tempo de manufatura e, consequentemente, reduzir as emissões de dióxido de carbono (CO2) da impressora (Pergunta 9).

Com relação aos processos tradicionais de manufatura, a entrevistada assevera que o processo de impressão dos produtos consome, em média, 50\% menos água e energia (Pergunta 14).

Quando perguntada se a empresa adota transparência quanto aos seus fornecedores (Pergunta 8), a entrevistada respondeu positivamente, contudo, não forneceu detaIhes. Mais tarde, no decorrer da entrevista, ela citou que a empresa busca trabalhar com fornecedores nacionais, todavia, mediante a escassez destes, não é raro recorrer à importação de matéria-prima (Pergunta 17). De modo similar, quando questionada sobre por quais motivos acredita que a empresa seja um negócio de alto impacto (Pergunta 12), a entrevistada respondeu, tão somente, "porquê fazemos dinheiro e ajudamos o mundo".

Desse modo, em termos de produção sustentável, percebe-se que a Black Purpurin emprega como matéria-prima insumos de baixo impacto ambiental. Por vezes, a entrevistada demonstrou interesse em ampliar o uso de materiais ecologicamente eficientes para além do PLA e do PETG, mesmo que suas consumidoras não

necessariamente identifiquem seus produtos como portadores de valores pró-sustentabilidade. Assim, compreendidos os insumos, os processos e a trajetória da empresa-objeto deste artigo, a seguir, tecem-se trechos do relato da entrevistada à luz do consumo sustentável.

\subsection{Consumo sustentável}

Com ênfase no conceito de upcycling (incremento ao ciclo de vida útil de um produto, em tradução livre para o português), a marca Black Purpurin atua, hoje, na produção de produtos exclusivos para um público majoritariamente feminino. Sobre o perfil das consumidoras da marca, a entrevistada afirmou que compreende seu público-alvo como dimensionado por dois grupos distintos: (I) as consumidoras jovens, engajadas com as redes sociais da marca, porém, com pouco poder aquisitivo; e (II) as consumidoras entre 35 e 55 anos, que compram regularmente seus produtos, seja para consumo próprio ou para presentear terceiros. Para as consumidoras jovens, a marca direciona produtos como porta-celulares (Figura 2); enquanto para as consumidoras regulares, criam-se bolsas com novos designs e partes cambiáveis (Pergunta 18).

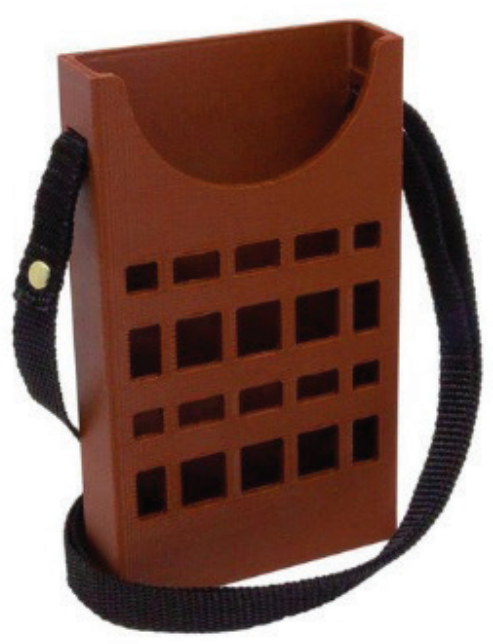

Figura 2: Porta-celular Black Purpurin Fonte: Loja Black Purpurin (2020)

A entrevistada também afirmou que uma parcela (metade) das consumidoras da marca não considera os aspectos sustentáveis dos produtos, apenas o design, e que outra parcela escolhe os produtos por se interessar pela impressão 3D, processo que lhe desperta a curiosidade imediata (Perguntas 13, 17 e 20). A entrevistada observa que, em geral, as consumidoras que optam pelo design acabam por realizar uma compra esporádica e que, dificilmente, retornam à loja. 
Já na perspectiva das consumidoras curiosas e, portanto, regulares, a entrevistada explica que, normalmente, há oportunidade de narrar a origem da matéria-prima e como o processo produtivo ocorre, o que acaba por servir como instrumento de persuasão no ato de compra (Perguntas 14 e 20). Também no ato de compra, é possível que as consumidoras personalizem a bolsa (Figura 3), adaptando-a a partir da seleção das partes que mais lhe interessam.

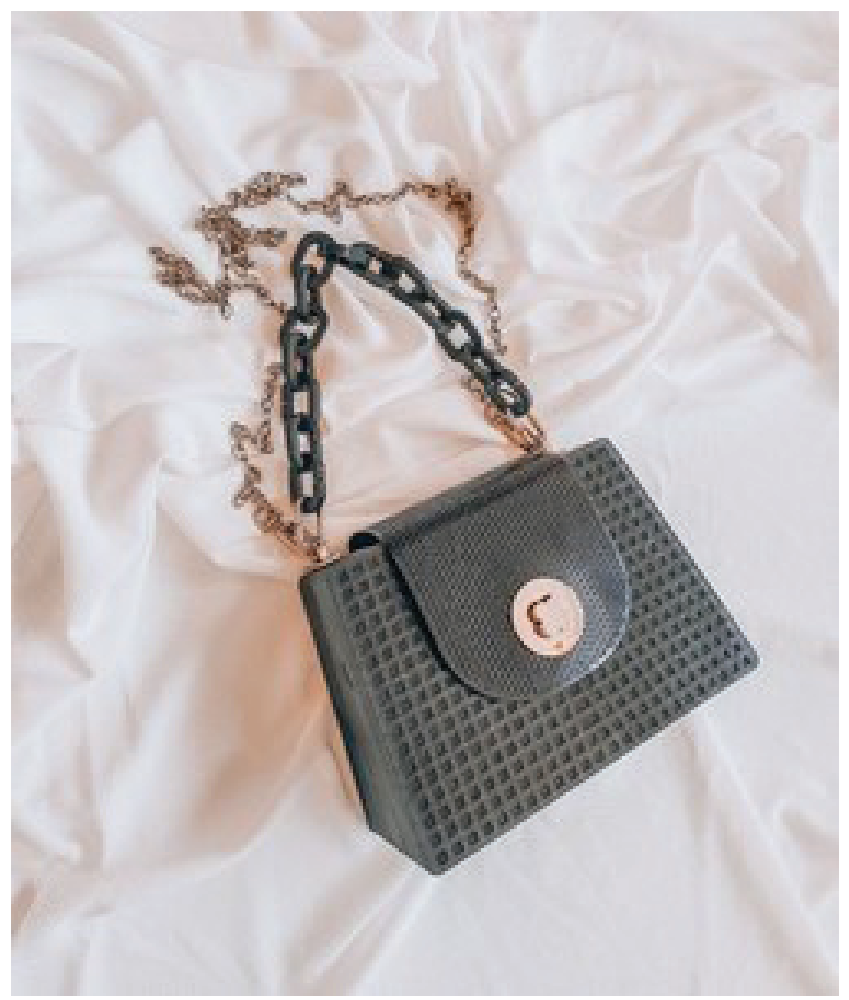

Figura 3: Bolsa Black Purpurin

Fonte: Loja Black Purpurin (2020).

A entrevistada cita que é possível gravar o nome da consumidora em uma placa metálica pequena para ser anexada ao produto (Pergunta 15). Outro reforço positivo comum no ato de compra mencionado ocorre quando as consumidoras são acompanhadas de seus cônjuges (Pergunta 18):

[...] os maridos se encantam com o produto, eles falam: "mulher ó, isso aqui, você precisa usar um negócio desses". E pelo fato da tecnologia, porque homem, às vezes, é muito ligado com a tecnologia, e [com a] impressora 3D, então, eles falam: "você precisa ter uma bolsa com esse negócio aqui, você precisa usar isso aí" [...].

Nesse sentido, as consumidoras curiosas que buscam entender as matérias-primas empregadas nos produtos da marca e seu processo de impressão, tornam-se, segundo a entrevistada, defensoras da empresa e passam a recomendá-la para seus círculos de amizade (Pergunta 20). Para a entrevistada, é comum as consumidoras regulares da marca relatarem que, quando portam os produtos em espaços públicos, transeuntes as abordam e perguntam se podem tocar a superfície dos produtos (Pergunta 10).

A entrevistada acredita que o diferencial da empresa está em propiciar para suas consumidoras a oportunidade de unir customização, exclusividade, design e sustentabilidade, ainda que este último fator não seja reconhecido por todas as suas consumidoras e tampouco seja uma das bandeiras da marca (Pergunta 15).

Nesse sentido, a Black Purpurin não considera a sustentabilidade um diferencial por entender que todas as empresas precisarão se adequar as normas que, futuramente, estarão em vigência (Perguntas 5 e 15). No entanto, a empresa acredita que mesmo a conscientização de suas consumidoras jovens e esporádicas pode ser desenvolvida durante o processo de compra em sua flagship store ou em seu e-commerce. A entrevistada demonstrou interesse em melhorar o produto por meio de investimento em matérias-primas inovadoras e menos nocivas ao meio ambiente, contudo, ressaltou que muitas consumidoras ainda não enxergam benefícios em produtos reciclados, o que a desencoraja na utilização da origem de sua matéria-prima como estratégia de diferenciação (Perguntas 5 e 20).

Logo, na perspectiva do consumo sustentável, observa-se que a marca se posiciona entre consumidoras que optam pelo design e por compras ocasionais e consumidoras regulares com comportamentos pró-sustentabilidade que emergem, espontaneamente, no ato de compra. Como reforço positivo para persuadir este grupo, não raro, narra-se o processo produtivo da marca. A seguir, o exemplo da Black Purpurin será discutido mediante a hipótese traçada inicialmente.

\section{DISCUSSÃO}

A hipótese inicial elaborada pelos autores era de que os consumidores locais da capital catarinense procuram a empresa por sua ênfase declarada na sustentabilidade e, de modo recíproco, que a empresa legitima o comportamento pró-sustentabilidade desses para além do ato de compra. Para verificação da hipótese diante do exemplo, elencaram-se quatro premissas: (I) a marca se autodeclara pró-sustentabilidade; (II) os consumidores locais a procuram por seu caráter ecofriendly; (III) a marca legitima o comportamento ambientalmente correto de seus consumidores no ato de compra; e (IV) a marca legitima o comportamento ambientalmente correto de seus consumidores em outras ações e oportunidades além do ato de compra. 
Para cada premissa, estipulou-se um conceito creditável com base no exemplo verificado: (I) refutada, se não confirmada no exemplo; (II) corroborada parcialmente, se confirmada, contudo, mediante adendos; e (III) corroborada, se confirmada em sua totalidade (Quadro 5).

\begin{tabular}{|l|l|}
\hline Premissas da hipótese & $\begin{array}{l}\text { Resposta mediante o } \\
\text { exemplo verificado }\end{array}$ \\
\hline $\begin{array}{l}\text { A marca se autodecla- } \\
\text { ra pró-sustentabilidade }\end{array}$ & Refutada \\
\hline $\begin{array}{l}\text { Os consumidores locais a procu- } \\
\text { ram por seu caráter ecofriendly }\end{array}$ & Refutada \\
\hline $\begin{array}{l}\text { A marca legitima o comportamen- } \\
\text { to ambientalmente correto de seus } \\
\text { consumidores no ato de compra }\end{array}$ & $\begin{array}{l}\text { Corroborada } \\
\text { parcialmente }\end{array}$ \\
\hline $\begin{array}{l}\text { A marca legitima o comportamen- } \\
\text { to ambientalmente correto de seus } \\
\text { consumidores em outras ações e } \\
\text { oportunidades além do ato de compra }\end{array}$ & Refutada \\
\hline
\end{tabular}

Quadro 5: Discussão das premissas da hipótese Fonte: Autores.

Conforme faz-se possível observar no Quadro 5, as premissas da hipótese foram refutadas em sua maioria. Acredita-se que isso ocorreu em função de que, após a entrevista, evidenciou-se que a empresa não possui uma ênfase declarada na sustentabilidade. Conforme narrou a entrevistada, a Black Purpurin não utiliza da sustentabilidade como uma bandeira da marca ou em ações de marketing, pois seus proprietários acreditam nela como um requisito básico para os futuros negócios de Moda.

Já a recíproca - legitimação do comportamento pró-sustentabilidade no ato de compra - ocorre apenas ocasionalmente. Nessas oportunidades, não são tecidos reforços positivos sobre o estilo de vida sustentável, tampouco sobre hábitos de consumo ético. O que ocorre é a descrição do processo produtivo com destaque para a tecnologia envolvida na impressão 3D. Portanto, essa premissa foi corroborada apenas parcialmente.

Logo, mediante os resultados alcançados, os autores acreditam que a hipótese foi refutada na verificação do exemplo. Isto é, a marca não se autodeclara pró-sustentabilidade, tampouco os consumidores locais a buscam por tal razão e, ainda, quando esses efetivam uma compra, apenas ocasionalmente têm seu comportamento legitimado pela marca, o que ocorre tão somente no momento do ato de compra.

\section{CONSIDERAÇÕES FINAIS}

Da Revolução do Consumo do século XVI até a transposição da sociedade do trabalho para a sociedade imagética na contemporaneidade, a expansão da dinâmica da Moda fez-se presente por meio da proposta de novas materialidades que, por sua vez, transcenderam e continuam a transcender o vestuário. Nessa dinâmica, os mecanismos de formação das identidades dos sujeitos hodiernos, que representam e fantasiam a si mesmos, podem ser respaldados pelo capital econômico, pelo valor simbólico dos bens materiais e pelo jogo da aparência.

Nesse sentido, quando o valor simbólico pende para a sustentabilidade e a relação pessoa-objeto passa a abarcar lições sobre a economia verde mais do que sobre a performance da estética, surgem consumidores dissidentes do outrora consagrado consumo civilizatório, antes próprio à ideologia American Way of Life. Então ditos consumidores éticos, esses sujeitos encontram solo fértil para validação de suas escolhas pessoais no consumo e na produção de bens materiais sustentáveis - premissa central do ODS 12 e tópico balizador da literatura investigada neste artigo.

Acerca da ecomoda e do consumo ético, o artigo explorou o exemplo da Black Purpurin, uma empresa florianopolitana focada na confecção de bolsas e de acessórios. Por intermédio de entrevista, observou-se que a empresa orbita o consumo ético sem, necessariamente, utilizar de bandeiras pró-sustentabilidade, como a ecomoda, enquanto diferenciais no ato de compra.

Quanto ao objetivo proposto - verificar por meio de um negócio de Moda, de Florianópolis (SC), como se configura o consumo sustentável localmente - os autores do artigo acreditam que, conforme relatado pela entrevista$\mathrm{da}$, os consumidores locais buscam exercer o consumo por intermédio dos aspectos estético-formais da materialidade. Isto implica dizer que, segundo o exemplo verificado, o design do produto sobrepõe-se ao critério sustentável. Somados à aparência, a customização, a exclusividade e o processo produtivo em impressão 3D são fatores autodeclarados pela marca e valorizados por suas consumidoras.

Por fim, para futuros estudos, sugere-se a ampliação do corpo de conhecimento aqui construído, bem como a expansão da investigação a outros exemplos de negócios de Moda. Recomenda-se, também, que sejam realizadas entrevistas com consumidores locais a fim de se averiguarem comportamentos pró-sustentabilidade.

\section{REFERÊNCIAS}

BARBIERI, José Carlos. Desenvolvimento e meio ambiente: as estratégias de mudanças da Agenda 21. 12. ed. Petrópolis: Editora Vozes, 2011.

BERGMANN, Carine. Fórum Brasil ODS 2019 reúne mais de $\mathbf{5 0 0}$ pessoas em Florianópolis e apresenta os ganhadores do Prêmio ODS SC. [S. I.]: Movimento 
Nacional ODS, 12 jul. 2019. Disponível em: https://bit. ly/3cw98Hz. Acesso em: 2 abr. 2020.

BRAGA, João. História da moda: uma narrativa. 7. ed. São Paulo: Editora Anhembi Morumbi, 2007.

FAJARDO, Elias. Consumo consciente, comércio justo: conhecimento e cidadania como fatores econômicos. Rio de Janeiro: SENAC Nacional, 2010.

FIGUEIRÓ, Nelso. Agenda 21 - conceitos básicos: o caminho para o desenvolvimento sustentável. Florianópolis: EPAGRI/CIRAM, 2001.

GIL, Antônio Carlos. Métodos e técnicas de pesquisa social. 6. ed. São Paulo: Atlas, 2008.

GONÇALVES-DIAS, Sylmara Lopes Francelino; MOURA, Carla. Consumo sustentável: muito além do consumo "verde". In: ENCONTRO DA ASSOCIAÇÃO NACIONAL DE PÓS-GRADUAÇÃO E PESQUISA EM ADMINISTRAÇÃO, 31., 2007, Rio de Janeiro. Anais [...]. Rio de Janeiro: Associação Nacional de Pós-graduação e Pesquisa em Administração, 2007. p. 1-13. Disponível em: https:// bit.ly/342z3CH. Acesso em: 16 mar. 2020.

HAUG, Anders; BUSCH, Jacob. Towards an Ethical Fashion Framework. Fashion Theory, [s. I.], v. 20, n. 3, p. 317-339, set. 2015. Disponível em: https://bit.ly/ 369GpHd. Acesso em: 28 mar. 2020.

IPEA - INSTITUTO DE PESQUISA ECONÔMICA APLICADA. Objetivos de Desenvolvimento Sustentável. Consumo e Produção Sustentáveis. [S. I.], 2019. Disponível em: https://bit.ly/331J5Vp. Acesso em: 3 abr. 2020.

KOTLER, Philip; KARTAJAYA, Hermawan; SETIAWAN, Iwan. Marketing 3.0: as forças que estão definindo o novo marketing centrado no ser humano. Rio de Janeiro: Campus, 2010.

LIMA, Mírian Cristina de et al. O consumo de produtos de moda baseado na vertente da sustentabilidade ambiental. Dapesquisa, Florianópolis, v. 13, n. 21, p. 25-42, dez. 2018. Disponível em: https://bit.ly/2S3miCg. Acesso em: 24 mar. 2020.

LIPOVETSKY, Gilles. 0 império do efêmero: a moda e seu destino nas sociedades modernas. São Paulo: Companhia de Bolso, 2009.

LOJA BLACK PURPURIN. Black Purpurin: Moda 3D. 2020. Disponível em: https://bit.ly/2G5Z5Ng. Acesso em: 14 set. 2020.

MARASCIULO, Marília. Raquel queria mudar de carreira. Juliano tinha uma impressora 3D. Conheça a Black Purpurin, que imprime bolsas fashionistas. [S. I.]: PROJETO DRAFT, 29 jan. 2020. Disponível em: https://bit.ly/2G7ZNcP. Acesso em: 14 mar. 2020.
MATTHEWS, Rachel. Contemporary fashion tastemakers: starting conversations that matter. Catwalk: The Journal of Fashion, Beauty and Style, Oxford, UK, v. 4, n. 1, p. 51-70, 2015. Disponível em: https://bit.ly/3i7Ftpc. Acesso em: 15 mar. 2020.

MCCRAKEN, Grant. Cultura \& Consumo: novas abordagens ao caráter simbólico dos bens e das atividades de consumo. Rio de Janeiro: Mauad, 2003. Tradução de: Fernando Eugênio.

MINISTÉRIO DAS RELAÇÕES EXTERIORES DO BRASIL (ed.). Objetivos do Desenvolvimento Sustentável. Rio de Janeiro, 11 fev. 2016. Disponível em: https://bit. ly/2HyYswv. Acesso em: 12 fev. 2020.

MIRANDA, Ana Paula de. Consumo de moda: a relação pessoa-objeto. São Paulo: Estação das Letras e Cores, 2008.

MORELLI, Graziela. Do Empréstimo a Não Posse: novas perspectivas no consumo de produtos e serviços. Palhoça: Novas Edições Acadêmicas, 2018.

MORGENSTERN, Elenir Carmen; WITKOSKI, Silvana Silva Reiter. Consumismo: uma reflexão acerca das aquisições no campo da moda. Mix Sustentável, Florianópolis, v. 4, n. 3, p. 67-75, out./mar. 2018. Disponível em: https://bit.ly/3cyQb79. Acesso em: 24 set. 2020.

ONU — ORGANIZAÇÃO DAS NAÇÕES UNIDAS. Agenda 2030: Objetivos de Desenvolvimento Sustentável. [S. I.], 13 out. 2015. Disponível em: https://bit.ly/30bj5oP. Acesso em: 13 fev. 2020.

SANT'ANNA, Mara Rúbia. Teoria de Moda: sociedade, imagem e consumo. 2. ed. rev. e atual. São Paulo: Estação das Letras e Cores, 2016.

SCHULTE, Neide Köhler. Reflexões sobre moda ética: contribuições do biocentrismo e do veganismo. Florianópolis: Editora da UDESC, 2015.

SOLOMON, Michael Robert. O comportamento do consumidor: comprando, possuindo e sendo. 9. ed. Porto Alegre: Bookman, 2011.

TROMBINI, Jéssica. Prêmio CERTI de Inovação relembra início do ecossistema de Florianópolis. [S. I.]: Centros de Referência em Tecnologias Inovadoras - CERTI Insights, 6 dez. 2019. Disponível em: https:// bit.ly/3i1ps49. Acesso em: 6 abr. 2020.

UN - UNITED NATIONS. Sustainable Development Goals Knowledge Platform. Progress of Goal in 2019. [S. I.], 2019. Disponível em: https://bit.ly/2S1Ox4I. Acesso em: 14 mar. 2020.

UNITED NATIONS. Sustainable Development Goals Knowledge Platform. United Nations Conference 
on Sustainable Development, Rio+20. [S. I.], 2020. Disponível em: https://bit.ly/3mWJxwq. Acesso em: 17 mar. 2020.

ZANIRATO, Sílvia Helena; ROTONDARO, Tatiana. Consumo, um dos dilemas da sustentabilidade. Estudos Avançados, [S. I.], v. 30, n. 88, p. 77-92, 2016. 10.1590/S0103-40142016.30880007. Disponível em: https://bit.ly/2Ga9wQ0. Acesso em: 2 abr. 2020.

\section{AUTORES}

ORCID: https://orcid.org/0000-0002-5298-4756

VALDECIR BABINSKI JÚNIOR | Instituto Federal de Santa Catarina - IFSC, Curso Superior de Tecnologia em Design de Moda, Jaraguá do Sul, SC, Brasl | Correspondência para: Rua Arthur Gunther, n. 225, apartamento 205, bloco 2 - bairro Amizade, Jaraguá do Sul-SC, 89255-570.|e-mail:vj.babinski@gmail.com

ORCID: https://orcid.org/0000-0001-8725-5214

PAULA MARTIN | Universidade do Sul de Santa Catarina Unisul - Relações Internacionais, Florianópolis, SC, Brasil Correspondência para: Servidão Anna Luisa Conceição, n. 570 - bairro São João do Rio Vermelho, Florianópolis - SC, 88060-325. | e-mail: paula.brag@gmail.com

ORCID: https://orcid.org/0000-0003-1708-1487

MARIANA LUÍSA SCHAEFFER BRILHANTE | Universidade do Estado de Santa Catarina (UDESC) | Programa de Pós-Graduação em Design de Vestuário e Moda (PPGModa), Florianópolis, SC | Correspondência para: Madre Benvenuta, n. 1907 - Bairro Itacorubi, Florianópolis - SC, 88035-901 | e-mail: marsbxx@gmail.com

ORCID: https://orcid.org/0000-0002-8429-2754

LUCAS DA ROSA, Dr. | Universidade do Estado de Santa Catarina (UDESC)|Programa dePós-Graduaçãoem Design deVestuário e Moda (PPGModa), Florianópolis, SC. | Correspondência para: Av. Madre Benvenuta, n. 1907 - Bairro Itacorubi, Florianópolis SC, 88035-901.| e-mail: darosa.lucas@gmail.com

ORCID: https://orcid.org/0000-0002-0602-0198

DULCE MARIA HOLANDA MACIEL, Dra. | Universidade do Estado de Santa Catarina | PPGModa | Florianópolis, SC. Correspondência para: Av. Madre Benvenuta, n. 1907 Bairro Itacorubi, Florianópolis - SC, 88035-901| e-mail: dulceholanda@gmail.com

\section{COMO CITAR ESTE ARTIGO}

BABINSKI JÚNIOR, Valdecir; MARTIN, Paula;BRILHANTE, Mariana Luísa Schaeffer; ROSA, Lucas da; MACIEL, Dulce Maria Holanda. Moda E Consumo Sustentável: Um Exemplo De Florianópolis (SC). MIX Sustentável, [S.I.], v. 7, n. 1, p. 93-110, dez. 2020. ISSN 24473073. Disponível em:<http://www.nexos.ufsc.br/index.php/ mixsustentavel>. Acesso em: dia mês. ano. doi:https:// doi.org/10.29183/2447-3073.MIX2020.v7.n1.93-110

DATA DE ENVI0: 30/07/2020

DATA DE ACEITE: 29/09/2020 